\title{
The Differential Axonal Degradation of Ret Accounts for Cell-Type-Specific Function of Glial Cell Line-Derived Neurotrophic Factor as a Retrograde Survival Factor
}

\author{
Cynthia C. Tsui ${ }^{1}$ and Brian A. Pierchala ${ }^{2}$ \\ ${ }^{1}$ Department of Internal Medicine-Nephrology Division, School of Medicine, and ${ }^{2}$ Department of Biologic and Materials Sciences, School of Dentistry, \\ University of Michigan, Ann Arbor, Michigan 48109
}

\begin{abstract}
Glial cell line-derived neurotrophic factor (GDNF) is a neuronal growth factor critical for the development and maintenance of central and peripheral neurons. GDNF is expressed in targets of innervation and provides support to several populations of large, projection neurons. To determine whether GDNF promotes retrograde survival over long axonal distances to cell bodies, we used a compartmentalized culture system. GDNF supported only modest and transient survival of postnatal sympathetic neurons when applied to their distal axons, in contrast to dorsal root ganglion (DRG) sensory neurons in which GDNF promoted survival equally well from either distal axons or cell bodies. Ret, the receptor tyrosine kinase for GDNF, underwent rapid proteasomal degradation in the axons of sympathetic neurons. Interestingly, the level of activated Ret in DRG neurons was sustained in the axons and also appeared in the cell bodies, suggesting that Ret was not degraded in sensory axons and was retrogradely transported. Pharmacologic inhibition of proteasomes only in the distal axons of sympathetic neurons caused an accumulation of activated Ret in both the axons and cell bodies during GDNF stimulation. Furthermore, exposure of the distal axons of sympathetic neurons to both GDNF and proteasome inhibitors, but neither one alone, promoted robust survival, identical to GDNF applied directly to the cell bodies. This differential responsiveness of sympathetic and sensory neurons to target-derived GDNF was attributable to the differential expression and degradation of the Ret 9 and Ret51 isoforms. Therefore, the local degradation of Ret in axons dictates whether GDNF family ligands act as retrograde survival factors.
\end{abstract}

\section{Introduction}

Glial cell line-derived neurotrophic factor (GDNF) is the founding member of the family of neuronal growth factors known as the GDNF family ligands (GFLs), which includes neurturin (NRTN), persephin, and artemin (ARTN) (Lin et al., 1993; Kotzbauer et al., 1996; Baloh et al., 1998; Milbrandt et al., 1998; Rosenblad et al., 2000). GDNF is responsible for neural development (Henderson et al., 1994; Arenas et al., 1995; Buj-Bello et al., 1995; Li et al., 1995; Mount et al., 1995; Oppenheim et al., 1995; Trupp et al., 1995), kidney morphogenesis (Moore et al., 1996; Pichel et al., 1996; Sánchez et al., 1996; Vega et al., 1996; Enomoto et al., 2000), and spermatogenesis (Meng et al., 2000; Jain et al., 2004). These functions are conveyed via activation of the receptor tyrosine kinase Ret (Durbec et al., 1996; Treanor et al., 1996; Vega et al., 1996). To activate Ret, GDNF first binds with high affinity to the coreceptor GDNF receptor $\alpha-1(\mathrm{GFR} \alpha 1)$, and then as a complex, GDNF and GFR $\alpha 1$ bind and activate Ret (Jing et al., 1996; Treanor et al., 1996; Sanicola et al., 1997; Cacalano et al.,

Received 0ct. 22, 2009; revised Jan. 26, 2010; accepted Feb. 8, 2010.

This research was supported by National Institutes of Health Grants K01 NS045221 and R01 NS058510 and New York State Spinal Cord Injury Research Board Idea Award C022044. Ret9 and Ret51 monoisoformic mice were a kind gift from Jeffrey Milbrandt. We thank Maura Munoz and John Frampton for expert technical assistance.

Correspondence should be addressed to Brian A. Pierchala, Department of Biologic and Materials Sciences, University of Michigan School of Dentistry, 1011 N. University, 3211 Dental, Ann Arbor, MI 48109. E-mail: pierchal@ umich.edu.

DOI:10.1523/JNEUROSCI.5246-09.2010

Copyright $\odot 2010$ the authors $\quad 0270-6474 / 10 / 305149-10 \$ 15.00 / 0$
1998). GDNF is also capable of promoting signaling events via binding to GFR $\alpha 1$ alone (Poteryaev et al., 1999; Trupp et al., 1999; Pozas and Ibanez, 2005) and, as a complex with a second receptor, neuronal cell adhesion molecule (Paratcha et al., 2003).

During development, neurotrophic factors are often expressed by targets of innervation, thus activating receptors on the growth cones and axon terminals of innervating neurons. Neurotrophic factors that convey long-distance retrograde axonal signals, such as neurotrophins, are critical regulators of targetdependent survival and maintenance (Levi-Montalcini, 1987). The functions of GFLs in vivo occur over both anatomically short and long distances. GDNF, for example, is critical for kidney morphogenesis and enteric precursor survival and migration (Moore et al., 1996; Pichel et al., 1996; Sánchez et al., 1996; Vega et al., 1996; Enomoto et al., 2000), which are both highly localized events. Conversely, GDNF is required for the development of sensory and motor neurons and is expressed either en route or at their targets of innervation (Trupp et al., 1995; Wright and Snider, 1996; Molliver et al., 1997; Garcès et al., 2000; Oppenheim et al., 2000; Haase et al., 2002; Whitehead et al., 2005; Albers et al., 2006; Kramer et al., 2006). Thus, GFLs likely have both short-distance and long-distance functions.

Sympathetic neurons of the superior cervical ganglion (SCG) in vivo do not retrogradely transport GDNF or NRTN, in contrast to sensory and motor neurons, which do retrogradely transport them (Yan et al., 1995; Leitner et al., 1999). If GFLs are a component of the retrograde signal itself, similar to the neurotrophins 
that require ligand-receptor complexes, then GFLs are not likely to be retrograde survival factors for sympathetic neurons in vivo but are likely to act in a retrograde manner for sensory neurons. In vitro studies, however, suggest that GDNF is capable of supporting the survival of SCG neurons when activating receptors on distal axons (Coulpier and Ibanez, 2004). To clarify the precise activity of GFLs in the retrograde survival of peripheral neurons, we used compartmentalized cultures of sympathetic and dorsal root ganglion (DRG) sensory neurons. Importantly, elucidation of the molecular determinants for the long-distance signaling capacities of GFLs will provide a more precise understanding of the physiologic functions of GFLs.

\section{Materials and Methods}

Compartmentalized cultures of primary neurons. Compartmentalized cultures of peripheral neurons (isolated from SCGs or DRGs) were assembled as described previously (Tsui-Pierchala and Ginty, 1999). Briefly, compartmentalized chambers (Camp10; Tyler Scientific) were placed onto culture dishes using silicone vacuum grease. Leaking chambers were identified by adding culture medium only in the side compartments and placing the chambers into a $37^{\circ} \mathrm{C}$ culture incubator overnight. After plating the neurons into the central cell body compartment, leakage was again tested by placing medium only into the central compartment and removing the medium from the side compartments. After incubation overnight, the chambers that leaked were identified, removed, and disassembled. To produce primary sympathetic neurons, SCGs were surgically dissected from embryonic day 20 (E20) to postnatal day 0 (P0) Sprague Dawley rat pups or E18 to P0 BALB/c mice (Charles River Laboratories). These ganglia were enzymatically dissociated and plated into the center compartments. For SCG neurons, the dishes were coated with rat tail collagen. For compartmentalized cultures of sensory neurons, DRGs from all spinal levels were dissected from E15 Sprague Dawley rats (Charles River Laboratories), dissociated, and plated into the compartmentalized chambers in a manner identical to the SCG neurons. DRG neurons were seeded onto the dishes that were coated with Matrigel (BD Biosciences). Glial cells were eliminated from the cultures by including 5-fluoro-2-deoxyuridine $(20 \mu \mathrm{M})$ and aphidicolin $(5 \mu \mathrm{g} / \mathrm{ml})$ in the culture medium (Sigma).

Neuronal treatments and survival assays. Sympathetic neurons were maintained in compartmentalized cultures for 5-6 d in vitro (DIV) (equivalent to P5 in vivo) before they were stimulated with GFLs. All compartmentalized cultures were maintained with NGF only in the distal axon compartments for $2 \mathrm{~d}$ before GFL stimulation. NGF was removed from the terminals, and blocking antibodies to NGF were added to all compartments. GDNF, NRTN, or ARTN were added to either the cell body or distal axon compartments at a $50 \mathrm{ng} / \mathrm{ml}$ concentration. In some cases, the cell bodies or axons were treated with NGF $(50 \mathrm{ng} / \mathrm{ml})$. For pharmacologic inhibition of proteasomes selectively on axons, epoxomicin (5 $\mu \mathrm{M}$; Biomol Research Laboratories) was added only to the distal axon compartments $30 \mathrm{~min}$ before stimulation with GDNF. In all negative controls, the appropriate vehicle was included at the same concentration (all GFLs were $1000 \times$ stock solutions in dilute acetic acid; epoxomicin was in a $500 \times$ stock in DMSO). Sensory neurons were maintained in compartmentalized cultures for 8 DIV (equivalent of P4) before being treated in the same manner as the sympathetic neurons. The NGFdependent population of DRG neurons was selected for, rather than the BDNF- and neurotrophin-3 (NT-3)-dependent populations, by only providing NGF ( $50 \mathrm{ng} / \mathrm{ml}$ ) to these compartmentalized cultures.

Survival experiments were conducted by first imaging the entire cell body compartment using an inverted microscope with a motorized stage (Carl Zeiss) just before the growth factor stimulation. The neurons were then reimaged every day for 4 consecutive days. The images taken at day 0 were compared with images taken on subsequent days, and the individual neurons were followed by a naive observer. Neurons that remained phase bright with smooth cell bodies were considered alive, whereas those that became phase dark with rough cell bodies and granulated, discontinuous processes were considered dead (Deckwerth and Johnson, 1993). The percentage of surviving neurons was calculated from these cell counts and compared over two to three independent dishes from three independent cultures. The percentage of apoptotic neurons was ascertained by staining the compartmentalized cultures on the last day of the experiment ( 48 or $96 \mathrm{~h}$ ) with Hoechst 33258 (Sigma). Neurons that had pyknotic nuclei (condensed nuclei, often with several small, bright blebs) were considered as undergoing apoptosis. The percentage of apoptotic cells was determined by comparing the number of apoptotic neurons with the total number of nuclei (apoptotic and alive) in each dish. The percentage of neuronal survival correlated closely with the percentage of apoptotic neurons measured using nuclear morphology.

Immunoprecipitations and immunoblotting. Compartmentalized cultures of sympathetic or sensory neurons were stimulated with GDNF (50 $\mathrm{ng} / \mathrm{ml}$ ) or NGF ( $50 \mathrm{ng} / \mathrm{ml}$ ) on the distal axons or cell bodies for the length of time described in each figure legend. The dishes were then placed on ice, gently washed twice with PBS, pH 7.4, and lysed with immunoprecipitation buffer [Tris-buffered saline (TBS), pH 7.4, 1\% Nonidet P-40, $10 \%$ glycerol, $500 \mu \mathrm{M}$ sodium vanidate, and protease inhibitors] as described previously (Tsui-Pierchala and Ginty, 1999; Tsui-Pierchala et al., 2002a). Ret51 was immunoprecipitated using Ret51-selective antibodies (C20; Santa Cruz Biotechnology), and these immunoprecipitates were subjected to SDS-PAGE followed by electroblotting onto polyvinylidene difluoride membranes (Immobilon P; Millipore Corporation). Western blot analysis was performed on these blots using phosphotyrosine antibodies to detect the amount of activated Ret (4G10; Millipore Corporation) and anti-Ret51 using an antibody that has been described previously (Tsui-Pierchala et al., 2002b). Supernatants from these immunoprecipitations served as loading controls and were subjected to anti-actin Western blot analysis (I19; Santa Cruz Biotechnology). In some cases, TrkA was analyzed via immunoprecipitation and Western blotting using a pan-Trk antibody (C14; Santa Cruz Biotechnology). Each biochemical experiment was performed two to three times with similar results. Quantifications of immunoblots were performed on scanned images of the films using NIH ImageJ software.

Cell surface biotinylation. Primary DRG neurons were gently placed on ice, washed with ice-cold PBS, and treated with sulfo-NHS-LC-Biotin (2 mM; Pierce) in PBS for $30 \mathrm{~min}$ on ice. The cells were then gently washed with TBS and detergent extracted using immunoprecipitation buffer. Cell surface, biotinylated proteins were purified using streptavidin agarose (Pierce). Supernatants from this streptavidin pulldown were then subjected to immunoprecipitation with Ret51 antibodies as described above. For biotinylation of the distal axons of compartmentalized cultures of SCG neurons, only the distal axon compartments were washed with PBS and subjected to biotinylation for $20 \mathrm{~min}$ at $4^{\circ} \mathrm{C}$ with sulfoNHS-LC-Biotin (1 mM in PBS; Pierce). The distal axon compartments were then washed with TBS, given normal culture medium and returned to the incubator before the treatments described in Results. Isolation of biotinylated proteins using streptavidin agarose was conducted as described above $24 \mathrm{~h}$ after the surface biotinylation of the distal axons.

Quantitative real-time reverse transcription-PCR. Primary SCG neurons grown on $35 \mathrm{~mm}$ plates were exposed to GDNF for 3 or $24 \mathrm{~h}$, or vehicle alone, before RNA extraction using the Absolutely RNA purification miniprep kit (Stratagene). cDNA was produced from this RNA (10 ng per reaction) by reverse transcription (RT) by using random primers and the AccuScript high-fidelity first-strand cDNA synthesis kit (Stratagene). Rat ret gene-specific probe-based primers were obtained from TaqMan Gene Expression Assays and used for the relative quantitative RT-PCR using an ABI Prism 7900HT Sequence Detector (Applied Biosystems). Glyceraldehyde-3-phosphate dehydrogenase (GAPDH) probe-based primers were used as the endogenous control. The quantification and normalization of results were based on computation of ret threshold cycle values $(\mathrm{Ct}$ ) and GAPDH Ct values. All samples were run in triplicate and repeated in two independent experiments. The relative expression and quantification analysis was performed using Sequence Detection Systems software (Applied Biosystems). 

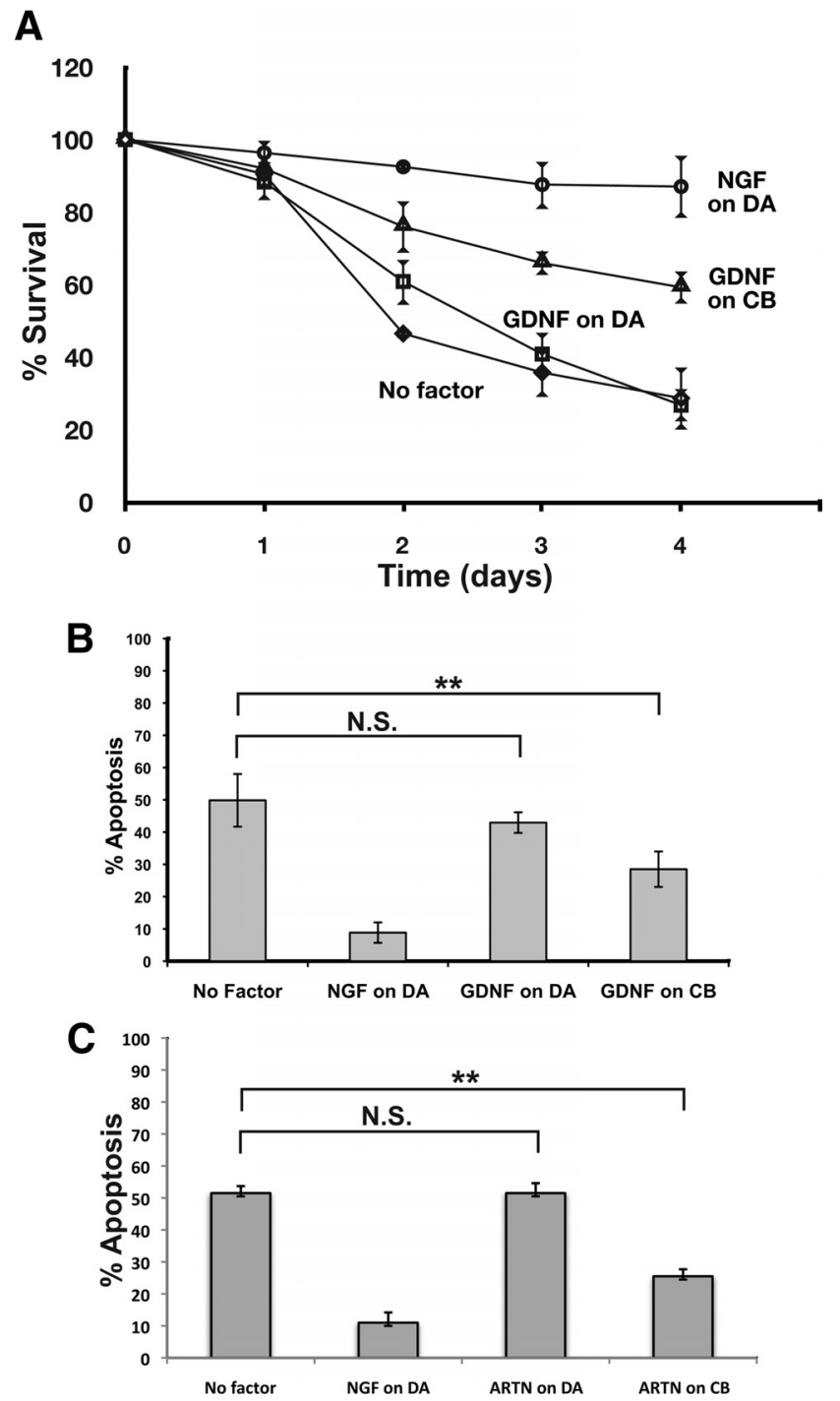

Figure 1. GFLs do not support the long-term retrograde survival of sympathetic neurons. Compartmentalized cultures of $S C G$ neurons were maintained in NGF only on the distal axons, and, after 5-6 DIV, NGF was removed from this compartment. The neurons were then treated with medium alone, NGF, or GDNF on their cell bodies (CB) or on their distal axons (DA). Each day thereafter, the entire cell body compartment was imaged, and the number of surviving neurons was determined by comparing these images with images captured just before the treatments (A). In $\boldsymbol{B}$, the number of apoptotic neurons was determined. Nuclei were stained with Hoechst 33258 after $48 \mathrm{~h}$ of growth factor stimulation, and the percentage of cells with condensed (pyknotic) nuclei was determined. $C$, The percentage of apoptotic neurons was ascertained after ARTN treatment of either the cell bodies or distal axons of sympathetic neurons. Three independent experiments were conducted for each panel, with two to three independent dishes measured for each condition in each experiment. Measurements of the percentage of apoptotic cells $(\boldsymbol{B}, \boldsymbol{C})$ correlated precisely with the survival data $(\boldsymbol{A})$. The data are graphed as the mean \pm SEM. ${ }^{* *} p<0.01 ;$ N.S., no statistically significant difference.

\section{Results}

GFLs do not support the long-term retrograde survival of sympathetic neurons

To determine whether GFLs can support the retrograde survival of sympathetic neurons, postnatal neurons from the SCG were established in compartmentalized cultures in which their distal axons projected into separate, fluid compartments (TsuiPierchala and Ginty, 1999). After 5-7 DIV, GDNF was applied only to the distal axons of these neurons. The survival of SCG neurons in response to GDNF applied to their axons was monitored using two independent methods. First, the percentage of

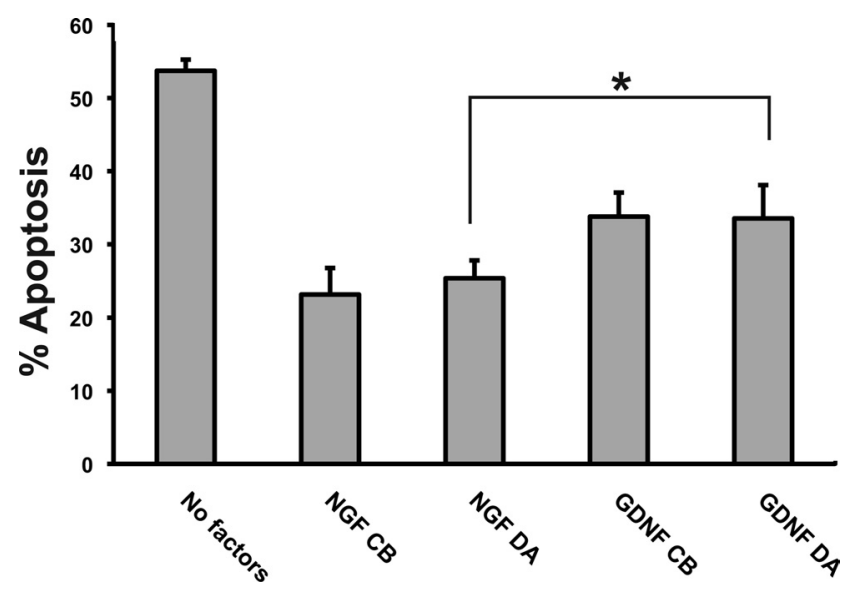

Figure 2. GDNF is a retrograde survival factor for DRG sensory neurons. Compartmentalized cultures of DRG neurons were maintained by NGF on the distal axons. After 8 DIV, NGF was removed and the neurons were then treated with medium alone, NGF, or GDNF on their cell bodies (CB) or on their distal axons (DA). The number of apoptotic cells were determined by staining the neurons with Hoechst 33258 and counting the number of cells with condensed nuclei. Three independent experiments were conducted on two to three independent dishes for each condition in each experiment. The data are graphed as the mean \pm SEM; ${ }^{*} p<0.05$. There was no significant difference in neuronal survival between GDNF applied to the cell bodies or distal axons.

surviving neurons was determined. This was accomplished by capturing phase-contrast images of the entire cell body compartment on the day of GDNF treatment (day 0). These same neurons were then reimaged $1,2,3$, and $4 \mathrm{~d}$ later. By comparing these images, individual neurons could be followed, and we were able to ascertain neurons that survived or died. Neurons were considered "dead" when they transitioned from having a smooth, round phase-bright cell body to having a phase-dark, atrophic, granulated cell body typical of SCG neurons undergoing apoptosis (Deckwerth and Johnson, 1993). Second, neuronal nuclei were stained with Hoechst 33258 at the end of the experimental treatments. The number of neurons that had pyknotic nuclei (condensed and fragmented nuclei) was counted, and a percentage of apoptotic neurons was determined.

GDNF, over the course of $4 \mathrm{~d}$, did not support the sustained survival of sympathetic neurons when only applied to the distal axons (Fig. $1 A, B$ ). GDNF promoted a modest survival at $2 \mathrm{~d}$ compared with the treatment of distal axons with medium alone, but this survival was transient and disappeared within 3-4 d (Fig. $1 A, B)$. In contrast, GDNF provided directly to the cell bodies supported the survival of $50-60 \%$ of sympathetic neurons, similar to what has been reported for mass cultures of rat sympathetic neurons (Fig. $1 A, B$ ). These results indicate that, although GDNF is capable of supporting the survival of sympathetic neurons when activating receptors on the cell body, GDNF does not support long-term survival across larger, retrograde distances. This is also in contrast to NGF, which supported the long-term survival of $>90 \%$ of neurons from the distal axons (Fig. $1 A, B$ ).

Sympathetic neurons express GFR $\alpha 1$, GFR $\alpha 2$, and GFR $\alpha 3$ and are capable of responding to GDNF, NRTN, and ARTN. ARTN is an axon guidance factor for embryonic sympathetic neurons that is expressed by the vasculature (Honma et al., 2002). To determine whether ARTN was capable of promoting survival in a retrograde manner, compartmentalized cultures of sympathetic neurons were exposed to ARTN directly on their distal axons. Although ARTN supported the survival of sympathetic neurons when provided directly to their cell bodies, ARTN could 
not support their survival from distal axons (Fig. 1C). This was again in contrast to NGF, which supported SCG neuron survival when applied to distal axons (Fig. $1 C)$. NRTN also did not support the longdistance survival of SCG neurons when provided to their distal axons (data not shown). Therefore, GFLs are not longterm retrograde survival factors for postnatal sympathetic neurons, although they are capable of supporting survival locally from cell bodies.

GDNF is a retrograde survival factor for sensory neurons

A subpopulation of nociceptive sensory neurons switch from expressing TrkA and requiring NGF for survival prenatally to expressing Ret and using GDNF and NRTN for their postnatal maintenance (Molliver et al., 1997; Luo et al., 2007). To determine whether GDNF supports the survival of sensory neurons when Ret is only activated on distal axons and terminals, compartmentalized cultures of DRG sensory neurons were examined. DRGs dissected from E15 rat embryos were enzymatically dissociated, plated into compartmentalized cultures, and initially supported by providing NGF to the axon terminals. These neurons were then given GDNF directly to the cell bodies or only to the distal axons, and the percentage of apoptotic neurons were examined $4 \mathrm{~d}$ later. In contrast to its effects on SCG neurons, GDNF supported a similar extent of survival regardless of whether it was applied to the distal axons or directly onto the cell bodies of DRG neurons (Fig. 2). NGF also inhibited the apoptosis of sensory neurons equally well from the distal axons and cell bodies (Fig. 2). NGF supported the survival of more sensory neurons than GDNF did, which is consistent with the observation that only a subset of TrkA-positive neurons switch their expression to Ret and are supported by GFLs (Molliver et al., 1997; Luo et al., 2007). These results indicate that GDNF is a retrograde survival factor for DRG sensory neurons, in contrast to sympathetic neurons.

Ret that is activated in distal axons of sympathetic neurons does not appear to be retrogradely transported, in contrast to sensory neurons

As a first step toward determining the mechanism responsible for the lack of retrograde GFL signaling in sympathetic neurons, the subcellular distribution of the GDNF receptor components was determined. Sympathetic neurons expressed Ret9, Ret51, and GFR $\alpha 1$ in both their distal axons and cell bodies (Fig. 3A). GFR $\alpha 1$ was enriched significantly in the distal axons compared with the cell bodies. There-

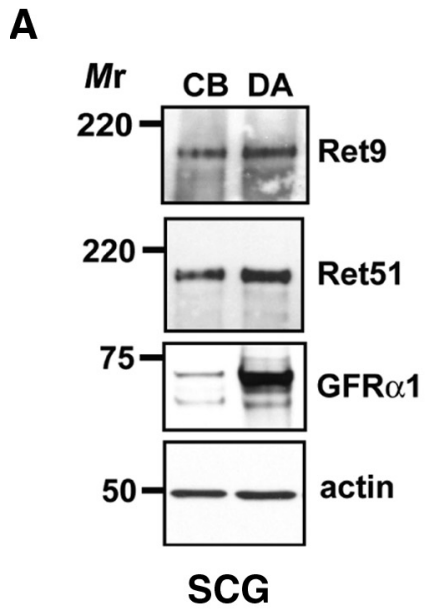

C
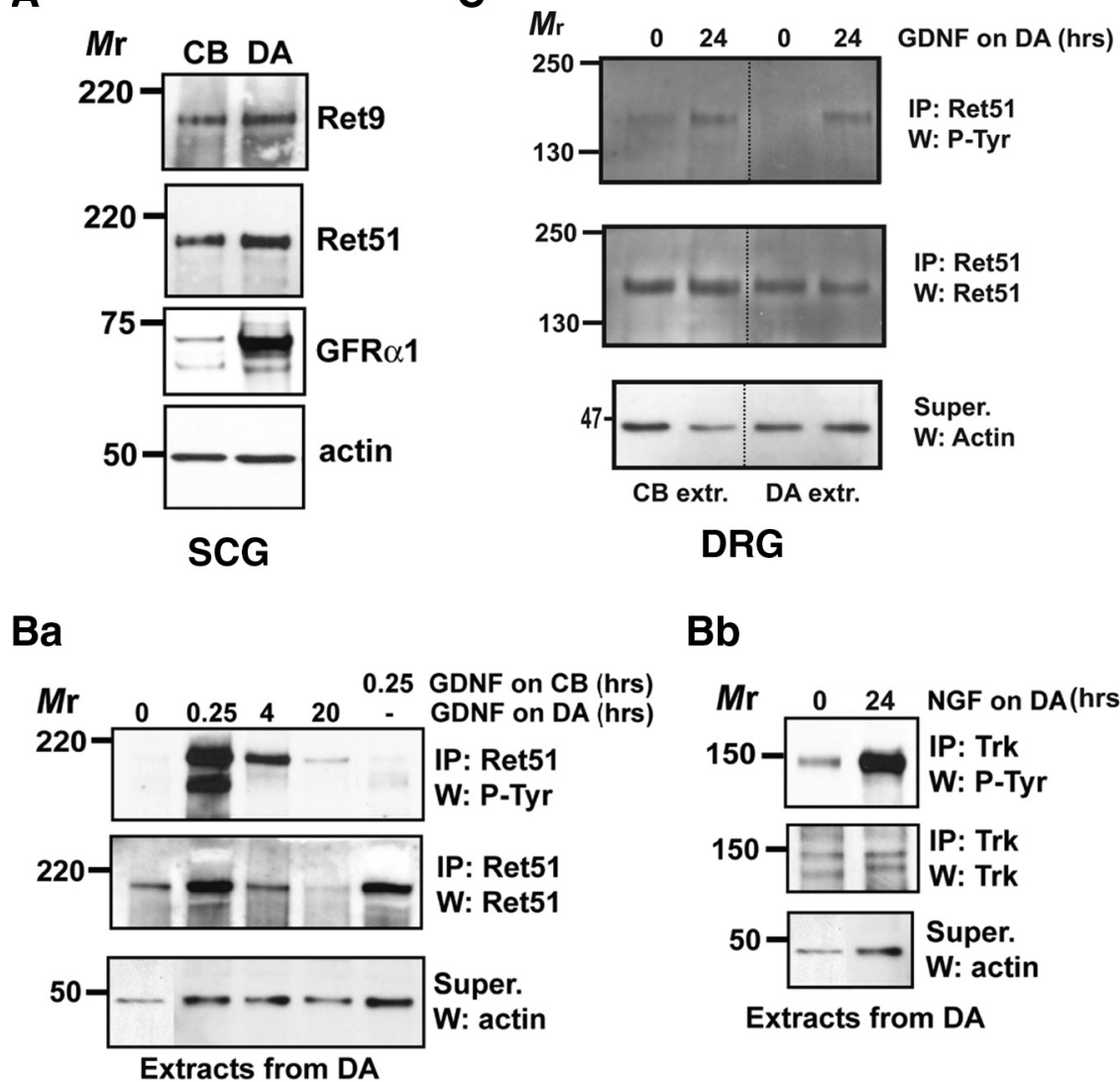

$\mathrm{Bb}$
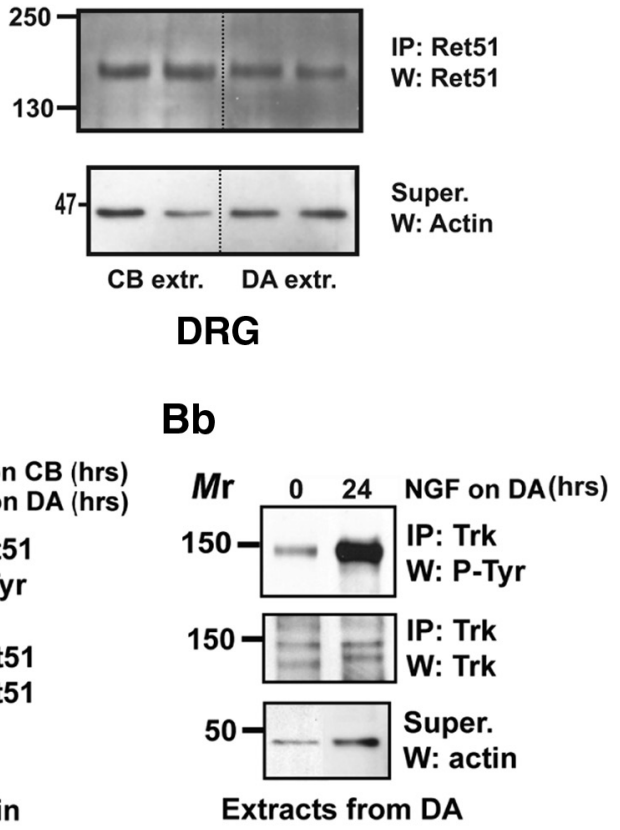

0.25 GDNF on CB (hrs)
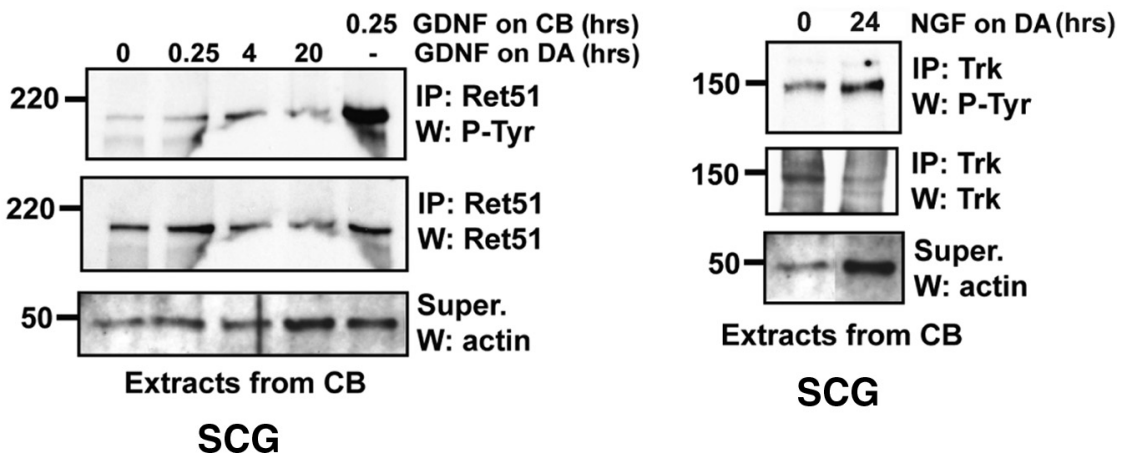

Figure 3. During activation, Ret is degraded locally in axons of sympathetic neurons but not sensory neurons. $\boldsymbol{A}$, Whole-cell extracts were produced from both the cell bodies (CB) and distal axons (DA) of sympathetic neurons that were maintained with NGF applied only to the distal axons. These extracts were then immunoblotted with antibodies to Ret9, Ret51, and actin as a control for the amounts of protein analyzed in each condition. Note that the amount of Ret 9 and Ret51 cannot be compared with each other because the primary antibodies have differing sensitivities. $\boldsymbol{B a}$, Compartmentalized cultures of sympathetic neurons were treated with medium alone or GDNF $(50 \mathrm{ng} / \mathrm{ml})$ on the distal axons for $15 \mathrm{~min}, 4 \mathrm{~h}$, or $20 \mathrm{~h}$. In a separate set of dishes, neurons were treated with GDNF directly on the cell bodies (labeled above the panels). The compartmentalized cultures were then detergent extracted, and these extracts from the cell body (CB; bottom 3 panels) and distal axon compartments (DA; top 3 panels) were subjected to Ret51 immunoprecipitation. These immunoprecipitates (IPs) were immunoblotted with phosphotyrosine antibodies and afterward were stripped and reprobed with Ret51 antibodies. Actin immunoblotting of the immunoprecipitation supernatants confirmed that similar amounts of protein were analyzed. $\boldsymbol{B} \boldsymbol{b}$, In an additional group of compartmentalized cultures analyzed simultaneously with the experiments described in $\mathbf{B a}$, the distal axons were treated with NGF $(50 \mathrm{ng} / \mathrm{ml})$ for $24 \mathrm{~h}$ and subjected to phospho-TrkA analysis in a similar manner to the Ret analysis. C, Compartmentalized cultures of DRG neurons were stimulated with medium alone or GDNF on the distal axons (DA). After $24 \mathrm{~h}$, the cell bodies and distal axons were detergent extracted and analyzed as in $\boldsymbol{B}$. These experiments were performed two to three times with similar results. Mr, Molecular weight; W, Western blot.

fore, the lack of a receptor component does not account for the failure of GDNF to support the retrograde survival of sympathetic neurons from distal axons.

Ret is rapidly degraded during its activation in sympathetic neurons, which is the predominant mechanism responsible for 
the termination of GDNF signaling in these cells (Pierchala et al., 2006). To examine the possibility that Ret activated in distal axons is degraded locally in axons, thereby limiting its capacity to be retrogradely transported and support retrograde survival, the levels of activated Ret were examined in compartmentalized cultures of SCG neurons. When sympathetic neurons were stimulated with GDNF only on their distal axons, Ret was robustly activated within $15 \mathrm{~min}$ in axons (Fig. $3 \mathrm{Ba}$ ). The levels of activated Ret declined over time and almost completely disappeared in the distal axons after $20 \mathrm{~h}$ of GDNF treatment (Fig. 3Ba). Importantly, the level of Ret51 itself rapidly declined in axons and was essentially absent after $20 \mathrm{~h}$ of GDNF stimulation. This was in stark contrast to the activation of TrkA by NGF, which supported the sustained activation of TrkA within distal axons for $>24 \mathrm{~h}$ of NGF stimulation (Fig. 3Bb). The extent of the retrograde appearance of activated Ret in the cell bodies of these neurons was also examined. Phosphorylated Ret did not appear in the cell bodies of SCG neurons, even after $20 \mathrm{~h}$ of GDNF treatment, suggesting that activated Ret was not retrogradely transported from the distal axons of sympathetic neurons to the cell bodies. Direct activation of Ret located in cell bodies with GDNF confirmed that we were able to detect the appearance of activated Ret in cell bodies, but that there was no detectible movement of activated Ret from the distal axons to the cell bodies (Fig. 3Ba). This again was in contrast to NGF stimulation of the distal axons of SCG neurons, which resulted in the significant appearance of activated TrkA in their cell bodies (Fig. 3Bb). Together, these data suggest that Ret, during activation in distal axons, is not retrogradely transported at detectible levels to the cell bodies of sympathetic neurons, in contrast to TrkA activated by NGF.

To determine whether the retrograde movement of activated Ret could be detected in sensory neurons, DRG neurons maintained in compartmentalized cultures were stimulated with GDNF only on their distal axons. The levels of phosphorylated Ret were then determined biochemically in the axons and cell bodies. Even $24 \mathrm{~h}$ after GDNF stimulation, activated Ret was sustained in the distal axons and also appeared in the cell bodies (Fig. 3C). The levels of Ret51 itself were also sustained in the distal axons and terminals of sensory neurons, suggesting that activated Ret was not degraded rapidly in sensory neurons and could be retrogradely transported to cell bodies (Fig. 3C). It should be noted that there was no anterograde appearance of activated Ret in the distal axons of SCG neurons after activation of receptors on their cell bodies (Fig. 3Ba), indicating that activated Ret only moves retrogradely. Together, these results suggest that activated Ret was rapidly degraded in SCG neurons that eliminated its retrograde movement to cell bodies, in contrast to DRG neurons. Interestingly, these biochemical data correlate with the absence of retrograde survival of SCG neurons in response to GDNF, along with the ability of DRG neurons to be supported by "targetderived" GDNF.

\section{Proteasomal degradation of Ret locally in the axons} of sympathetic neurons limits the survival-promoting effects of GDNF

During activation, Ret51 is degraded predominantly by the proteasome (Pierchala et al., 2006). To determine whether the loss of activated Ret from the axons of sympathetic neurons is attributable to its local proteasomal degradation in axons, proteasome inhibitors were used. When proteasomes were inhibited pharmacologically only in the distal axons (epoxomicin, $5 \mu \mathrm{M}$ ) and these axons were stimulated with GDNF, a high level of activated Ret was sustained, even after $24 \mathrm{~h}$ of GDNF stimulation (Fig. $4 A$ ).
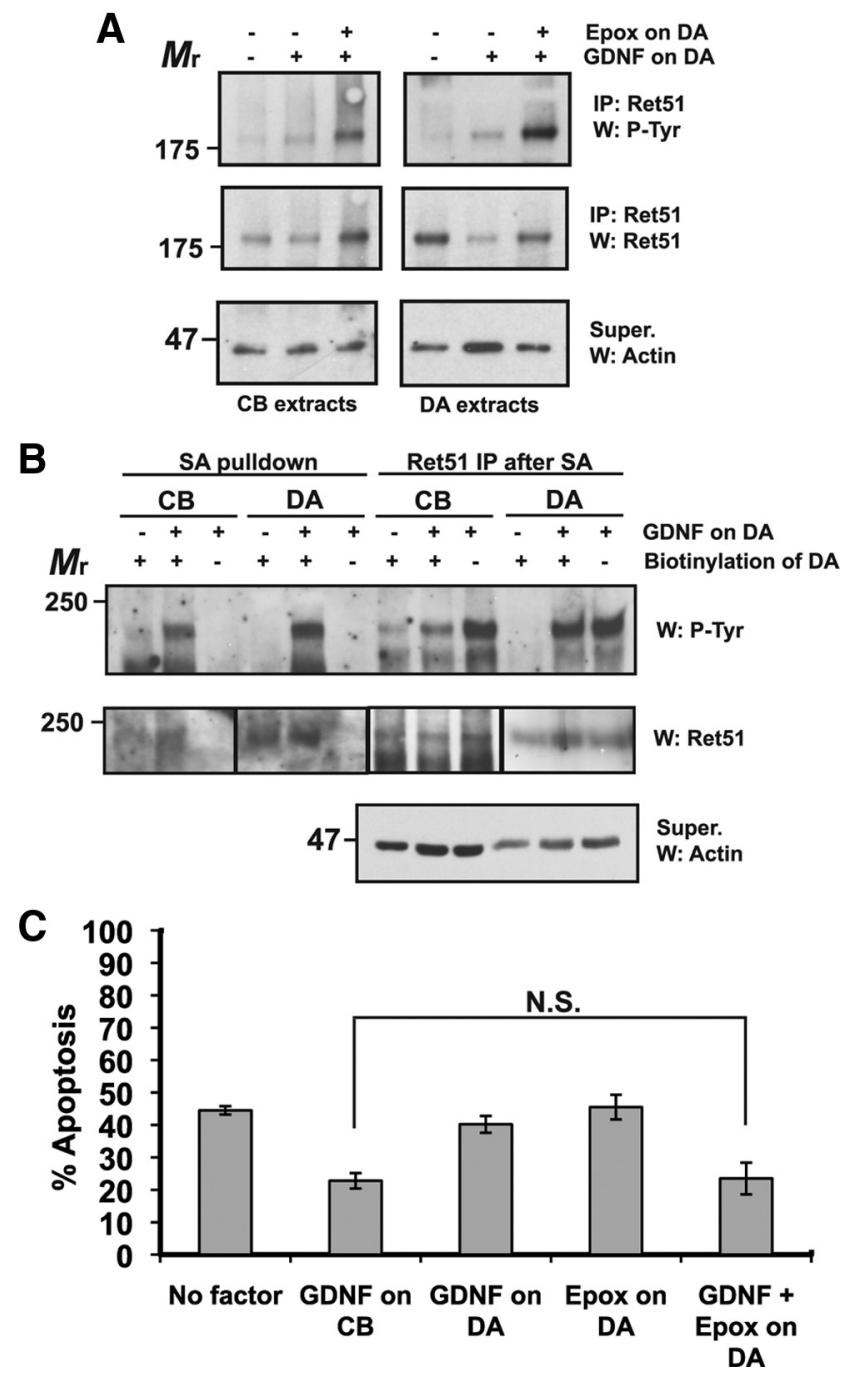

Figure 4. The axonal degradation of activated Ret limits the retrograde signaling capacity of GDNF. A, Compartmentalized cultures of SCG neurons were treated with medium alone, GDNF, or GDNF with epoxomicin only on their distal axons (DA). After $24 \mathrm{~h}$, the cell bodies and distal axons were detergent extracted, and the levels and phosphorylation status of Ret were analyzed as in Figure 3. B, Cell surface proteins of the distal axons of SCG neurons grown in compartmentalized cultures were biotinylated or exposed to buffer alone. The neurons were next stimulated with GDNF or medium alone in the presence of epoxomicin that was also applied only on the distal axons. Twenty-four hours later, biotinylated proteins were isolated using streptavidin agarose, and the remainder of Ret51 was immunoprecipitated from these supernatants of the streptavidin pulldown. The levels of phosphorylated Ret were analyzed as in $A$. C, Compartmentalized cultures of sympathetic neurons were maintained in NGF only on their distal axons for 6 DIV. These neurons were then treated with medium alone, GDNF on their cell bodies or on their distal axons, epoxomicin on their distal axons, or with GDNF and epoxomicin on their distal axons. The number of apoptotic neurons in each condition was determined as in Figure 1, and the data were graphed as the mean \pm SEM. CB, Cell body; DA, distal axon; IP, immunoprecipitation; Mr, molecular weight; N.S., no statistically significant difference; W, Western blot.

Activated Ret also appeared in the cell bodies of these neurons under these conditions (Fig. 4A). In contrast, stimulation of axons with GDNF alone led to the loss of Ret from the axon terminals, and there was no significant increase in the level of activated Ret in cell bodies after $24 \mathrm{~h}$ (Fig. 4A). To determine whether the activated Ret that appeared in the cell bodies was the result of retrograde transport of activated Ret from the distal axons, cell surface biotinylation experiments were conducted. Cell surface proteins only on the distal axons were labeled using a membrane- 

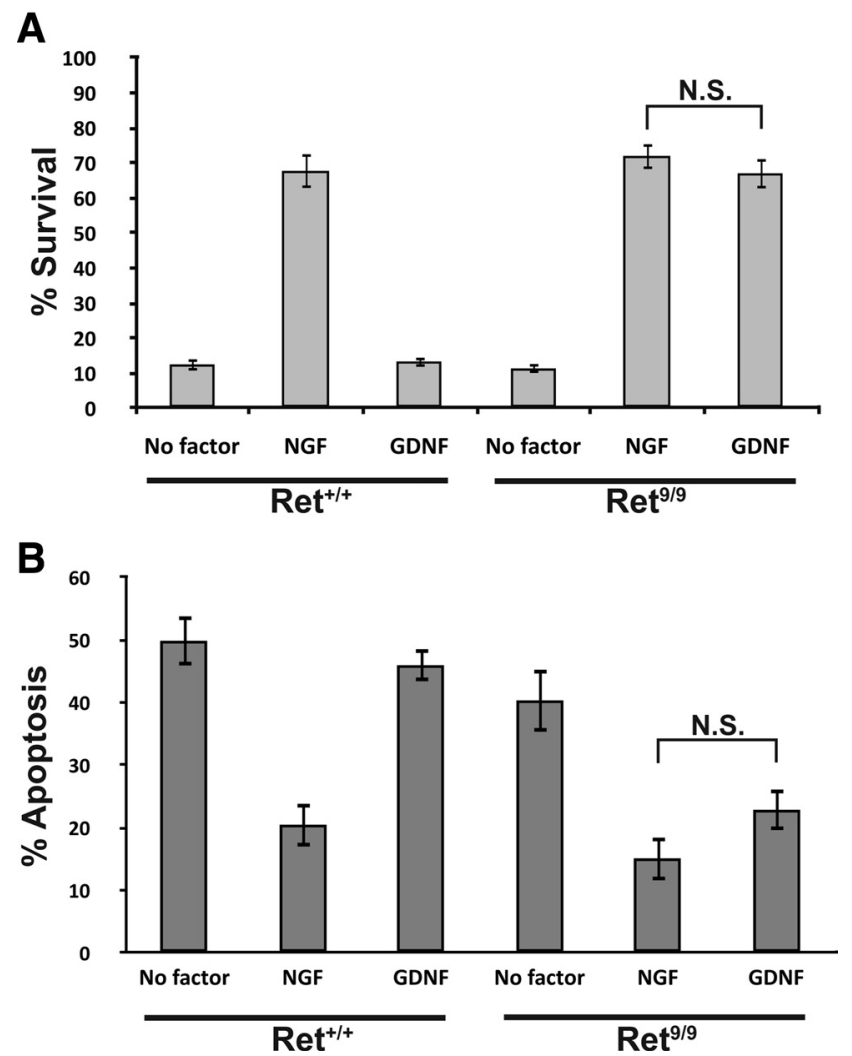

Figure 5. The level of Ret9 expression dictates whether the retrograde survival of sympathetic neurons can be supported by GDNF. Compartmentalized cultures of Ret ${ }^{+/+}$(left 3 columns) or Ret ${ }^{9 / 9}$ (right 3 columns) sympathetic neurons were maintained with NGF on their distal axons for 6 DIV, followed by the removal of this NGF. The neurons were then stimulated with medium alone, NGF, or GDNF only on their distal axons. The percentage of surviving neurons $(\boldsymbol{A})$ or the percentage of neurons undergoing apoptosis $(\boldsymbol{B})$ was determined after 4 or $2 \mathrm{~d}$ of stimulation, respectively. The data are graphed as the mean \pm SEM from two independent cultures of three to four chambers for each condition. N.S., No statistically significant difference.

impermeant biotinylation reagent that was added only to the axon compartments of compartmentalized cultures of sympathetic neurons. The distal axons of these neurons were then stimulated with GDNF or medium alone in the presence of proteasome inhibitors and, after $24 \mathrm{~h}$, the retrogradely transported proteins were isolated from the cell bodies using streptavidin agarose (Fig. 4B). Autophosphorylated, biotinylated Ret was detected in the cell bodies of sympathetic neurons only when their distal axons were stimulated with GDNF (Fig. 4B). As a control, no autophosphorylated Ret was detected in the streptavidin pulldown from GDNF-stimulated neurons that were not biotinylated, confirming the specificity of the streptavidin agarose. Ret51 immunoprecipitation of the supernatants from the streptavidin pulldowns confirmed that GDNF stimulation of axons activated Ret in a sustained manner (because of axonal proteasome inhibition) regardless of whether the distal axons were biotinylated or not (Fig. $4 B)$. As an additional control, we examined whether GDNF stimulation of sympathetic neurons may increase the transcription of Ret, thereby affecting the amount of total Ret observed in these neurons. To this end, quantitative RT-PCR of Ret mRNA was performed on sympathetic neurons stimulated with GDNF or medium alone. There was no major difference in the level of Ret mRNA after $24 \mathrm{~h}$ of GDNF stimulation of sympathetic neurons (fold change of ret expression relative to no GDNF treatment was $0.85 \pm 0.05$, mean \pm range). We also did not observe any differ-
A
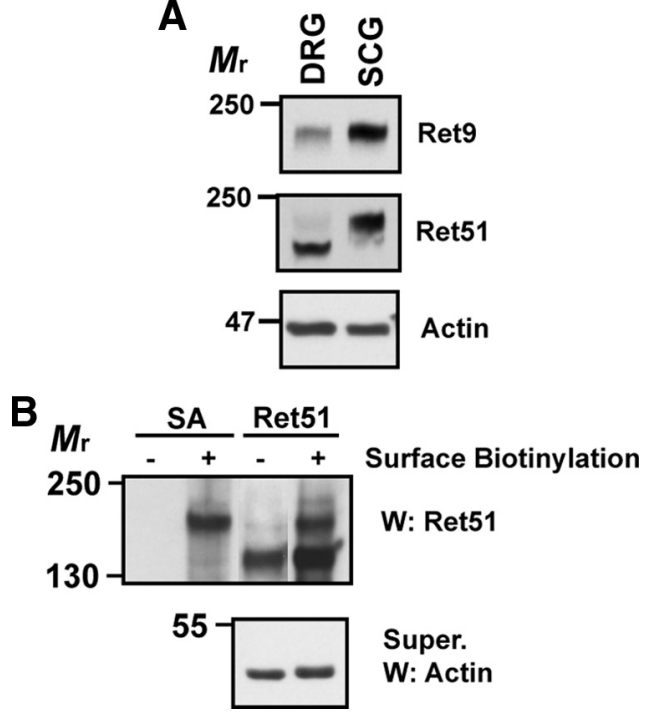

Figure 6. Sensory neurons express a higher ratio of Ret 9 to Ret51, in contrast to sympathetic neurons. $\boldsymbol{A}$, DRG sensory neurons that were maintained in NGF for 8 DIV and SCG neurons that were maintained in NGF for 6 DIV were washed and whole-cell extracted. The ratio of Ret 9 to Ret51 was compared between DRG and SCG neurons by immunoblotting with Ret9-selective and Ret51-selective antibodies. Actin immunoblotting served as a loading control. Because of the inherently different sensitivities of the Ret 9 and Ret 51 antibodies, the absolute abundance of Ret 9 and Ret51 cannot be ascertained in this manner. $\boldsymbol{B}$, DRG neurons maintained in NGF were subjected to cell surface biotinylation or to the buffer alone for $30 \mathrm{~min}$. The neurons were then washed thoroughly and detergent extracted, and biotinylated proteins were isolated using streptavidin agarose (SA). The remaining intracellular pool of Ret51 was then isolated from the streptavidin pulldown supernatants by Ret51 immunoprecipitation. These precipitations were analyzed by Ret51 immunoblotting, and the supernatants were immunoblotted with actin antibodies to confirm the analysis of similar amounts of protein. Mr, Molecular weight; W, Western blot.

ence in the expression of Ret mRNA after $3 \mathrm{~h}$ of GDNF treatment (data not shown), indicating that Ret activation did not upregulate its own transcription in primary sympathetic neurons. Together, these data indicate that, when Ret was activated by GDNF in distal axons, it was degraded in axons, thus preventing it from being retrogradely transported to the cell bodies.

To determine whether the axonal degradation of Ret accounts for the inability of sympathetic neurons to survive in response to GDNF applied only to the distal axons, the extent of sympathetic neuron survival was ascertained under this same set of conditions. As seen previously (Fig. 1), GDNF applied to the distal axons of sympathetic neurons did not prevent their apoptotic death (Fig. 4C). Application of proteasome inhibitors alone to the distal axons also did not support SCG neuron survival. Interestingly, stimulation of the distal axons of sympathetic neurons with GDNF in the presence of proteasome inhibitors supported their survival as effectively as GDNF provided directly to the cell bodies (Fig. 4C). These data demonstrate that the proteasomal degradation of activated Ret in the axons of sympathetic neurons prevents the generation of a retrograde GDNF signal that would support their survival.

The scarcity of Ret9 in sympathetic neurons accounts for their lack of retrograde GFL survival

It has been reported previously that SCG neurons express predominantly the Ret51 isoform of Ret (Tsui-Pierchala et al., 2002 b). In fact, SCG neurons have a 4:1 protein ratio of Ret51 to Ret9. Because Ret51 is the most rapidly degraded isoform and has a half-life of only $1 \mathrm{~h}$ (Scott et al., 2005; Pierchala et al., 2006), we 


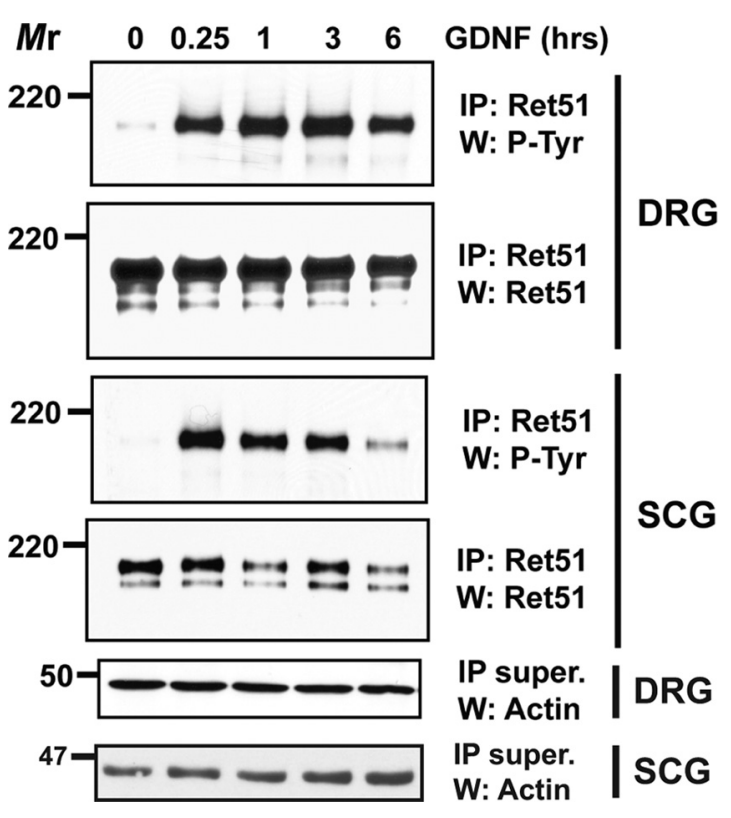

Figure 7. Ret51 is not rapidly degraded in sensory neurons. Primary cultures of DRG and SCG neurons were maintained in NGF for 8 or 6 DIV, respectively, and then stimulated with GDNF for the lengths of time indicated above the immunoblots. Ret51 was immunoprecipitated from each condition and analyzed by immunoblotting for phosphotyrosine or total Ret51. Actin served as a loading control for the immunoblotting. This experiment was performed three times with similar results. IP, Immunoprecipitation; Mr, molecular weight; W, Western blot. only Ret9 without any Ret51 (Ret9 monoisoformic mice). Sympathetic neurons from either Ret ${ }^{+/+}$or Ret ${ }^{9 / 9}$ mice were established in compartmentalized cultures until their axons emerged in the separate fluid compartments. There were no obvious morphological differences between Ret ${ }^{+/+}$neurons and Ret ${ }^{9 / 9}$ neurons when their survival was maintained with NGF (data not shown). When Ret ${ }^{9 / 9}$ neurons were stimulated with NGF only on the distal axons, their survival was equivalent to NGF-treated Ret $^{+/+}$neurons (Fig. 5A). Likewise, deprivation of NGF from the distal axons of these neurons lead to their equivalent apoptotic death, regardless of the amount of Ret9 that was expressed (Fig. $5 A$ ). Interestingly, GDNF applied only to the distal axons of $\mathrm{Ret}^{9 / 9}$ neurons promoted their survival robustly and was equivalent to NGF provided to the distal axons (Fig. 5A). This was in contrast to Ret ${ }^{+/+}$neurons in which no significant survival was observed after $4 \mathrm{~d}$ of GDNF treatment on the distal axons (Fig. $5 A$ ). Identical results were observed when the percentage of apoptosis was measured rather than survival (Fig. 5B). These data indicate that the considerably lower expression of Ret9 in SCG neurons, compared with Ret51, limits the survival of these neurons in response to target-derived GDNF because of the rapid degradation of the Ret51 isoform.

Sensory neurons express a higher ratio of Ret9 compared with Ret51 than sympathetic neurons

To ascertain why sensory neurons, unlike sympathetic neurons, are supported by GDNF when only activating receptors on their axons, the relative extent of Ret9 and Ret51 expression was examined. Wholecell extracts were produced from primary SCG and DRG neurons maintained in NGF for 6-9 DIV. These extracts were then analyzed for the expression of Ret9 and Ret5 1 by immunoblotting using antibodies specific for each Ret isoform. Although sympathetic and sensory neurons expressed both Ret 9 and Ret51, DRG neurons expressed lower amounts of both of these receptors compared with sympathetic neurons (Fig. 6A). In DRG neurons, a significant amount of a smaller form of Ret51 was sometimes observed in mass cultures (Fig. 6A), which is likely an immature form of Ret that is not fully glycosylated. Three independent cultures of SCG and DRG neurons were analyzed for mature, fully glycosylated Ret 9 and Ret5 1 expression, and these immunoblots were quantified. These analyses revealed that the relative ratio of Ret $9 /$ Ret 51 was almost twofold higher in sensory neurons compared with sympathetic neurons (mean \pm SEM of $1.37 \pm 0.69$ in DRGs vs $0.82 \pm 0.46$ in SCG neurons; significantly different with $p<0.01$ ), indicating that a higher percentage of Ret9 is expressed in sensory neu-

Figure 8. Proposed mechanism of GFL signal transduction from the axons of peripheral neurons. In SCG neur dependent activation of Ret results in the rapid degradation of Ret by the proteasomes of axons. This eliminates the possibility of the retrograde transport of an active ligand-receptor complex, thereby limiting the effects of GFLs to local events such as axon growth, guidance, and axonal maintenance. DRG sensory neurons, in contrast, do not degrade Ret51 during activation in axon terminals. This allows for the retrograde transport of active GFL-Ret complexes that are capable of regulating biochemical events in the cell body. Therefore, in DRG neurons, GDNF is capable of promoting survival and trophism of the cell body as well as local events in axons.

speculated that the levels of Ret9 are not sufficient to propagate a stable retrograde signal from the distal axons. Although Ret9 can be detected in the distal axons of SCG neurons (Fig. 3A), the relative amounts cannot be compared using these different antibodies to Ret9 and Ret51. To test the hypothesis that the level of Ret9 expression limits the retrograde GFL-mediated survival of sympathetic neurons, we examined knock-in mice that express rons than is Ret51. To determine whether the smaller form of Ret51 expressed in DRG neurons is an immature form of Ret51 that has not reached the plasma membrane, cell surface biotinylation was performed. Primary DRG neurons were exposed to either a membrane-impermeant, cell surface biotinylation reagent or vehicle alone, and cell-surface-labeled proteins were then isolated using streptavidin agarose. The remaining intracel- 
lular pool of Ret51 was immunoprecipitated from these supernatants, and both the cell surface and intracellular pools of Ret51 were visualized by Ret51 immunoblotting (Fig. 6B). The smaller $150 \mathrm{kDa}$ form of Ret51 was not located on the cell surface and was only present intracellularly, indicating that this is an immature form of Ret51. It should be noted that this immature form of Ret51 is not always detected in DRG neurons (as in Fig. 3C), and the regulation Ret51 maturation and trafficking are currently under investigation. Together, because Ret9 is degraded more slowly than Ret51, the relatively higher amount of Ret9 present in DRG neurons may account for the differences seen in the survival of DRG neurons when stimulated with GDNF on the distal axons.

\section{Ret51 is degraded during activation more slowly in sensory neurons than in sympathetic neurons}

Although a higher ratio of Ret9 to Ret51 may contribute the differential effects of GDNF on sensory neurons compared with sympathetic neurons, this does not explain the observation that activated Ret51 was more stable in the axons of DRG neurons than in SCG neurons (Fig. $3 B, C$ ). To determine whether the kinetics of Ret51 degradation after its activation are different between SCG and DRG neurons, a time course of GDNF treatment was performed. Both sympathetic and sensory neurons were treated with GDNF for $15 \mathrm{~min}, 1 \mathrm{~h}, 3 \mathrm{~h}$, or $6 \mathrm{~h}$, and the levels of Ret51 and activated Ret51 were determined. Ret51 was activated robustly in both SCG and DRG neurons within $15 \mathrm{~min}$ (Fig. $7)$. In sensory neurons, the level of Ret51 activation and Ret51 protein remained essentially unchanged after $6 \mathrm{~h}$ of GDNF stimulation (Fig. 7). In contrast, Ret activation declined significantly in sympathetic neurons, along with the level of Ret protein (Fig. 7). Quantification of immunoblots from two independent experiments indicated that $<20 \%$ of Ret 51 remained after $6 \mathrm{~h}$ of GDNF exposure in sympathetic neurons. These data indicate that Ret51 is degraded more rapidly in sympathetic neurons compared with sensory neurons, suggesting that differences in how sympathetic and sensory neurons process Ret51 during its activation dictates the extent of retrograde GDNF signaling.

\section{Discussion}

Peripheral neurons project axons across tremendous distances to reach their correct targets. This study was initiated to better understand how neurotrophic factors, such as GDNF, both guide axons en route and support the survival and maintenance of these neurons when making their proper connections. The long-term survival of sympathetic neurons was not supported by GDNF provided to their distal axons, in contrast to sensory neurons that were supported equally well by GDNF provided to either their cell bodies or axons. The retrograde appearance of activated Ret in the cell bodies when only distal axons were stimulated was observed in sensory neurons but not in sympathetic neurons, which correlated with the retrograde survival effects of GDNF (Fig. 8). A heightened expression of the Ret9 isoform of Ret, which is degraded considerably more slowly after its activation than Ret51, in sympathetic neurons enabled them to survive in response to target-derived GDNF. Consistent with the notion that the degradation of Ret in sympathetic neurons limited the long-distance signaling effects of GDNF, inhibition of proteasomal degradation of Ret in axons promoted both the retrograde transport of activated Ret and the retrograde survival of SCG neurons. Interestingly, sensory neurons expressed a greater proportion of Ret9 than Ret51 and also did not degrade Ret51 during its activation to the same extent as sympathetic neurons did. It is therefore likely that degradation pathways in neurons control whether growth factor signals are limited to regulating local events or are capable of promoting long-distance functions such as the survival and phenotypic maintenance of the neuronal cell body.

A previous study investigated the role of GDNF in the retrograde survival of sympathetic neurons in vitro using compartmentalized cultures and demonstrated the retrograde survival of SCG neurons by GDNF and the retrograde movement of GDNF and GFR $\alpha 1$ itself (Coulpier and Ibanez, 2004). Interestingly, this previous study examined the survival of SCG neurons after 9-10 DIV and the retrograde movement of GDNF at 15 DIV, a period during which the ability of NGF to inhibit the internalization and degradation of activated Ret is emerging (Tsui-Pierchala et al., $2002 \mathrm{a})$. In the results reported here, younger neurons were examined such that they were still highly growth factor dependent and closer to their developmental period of GFL-dependent axon guidance. These studies, when taken together, suggest that the responsiveness of a given neuron to target-derived neurotrophic factors depends on their developmental stage because of regulated alterations in receptor trafficking/degradation pathways.

The dramatic differences we observed between SCG and DRG neurons are in keeping with the physiological function of the GFLs in these neurons. Embryonic sympathetic neurons are guided by ARTN produced by the vasculature en route to their final targets (Honma et al., 2002). NGF acts as the target-derived survival factor for sympathetic neurons (Levi-Montalcini, 1987), and both ARTN and NT-3 likely only provide guidance information and promote axon growth, but do not support survival, during the process of axon pathfinding (Honma et al., 2002; Kuruvilla et al., 2004). Indeed, we found that GFLs were not capable of supporting the survival of sympathetic neurons when only activating Ret receptors on axons. Many postnatal DRG nociceptive neurons, conversely, after making the proper target connections, upregulate Ret and GFR $\alpha$ s and become responsive to target-derived GDNF and NRTN and require them for their postnatal maintenance (Molliver et al., 1997; Luo et al., 2007). Consistent with the physiological roles of these GFLs, DRG neurons were supported equally well by GDNF regardless of whether it activated receptors on axons or cell bodies.

The results reported here highlight the principle that subcellular growth factor signaling mechanisms dictate the physiology and development of peripheral neurons. Furthermore, these data indicate that the phenotypic response of a particular population of neurons to a neurotrophic factor in their environment may not be applicable to all neurons that express the same receptors. This spatial regulation of axonal signaling is critically important when considering the etiology of neurodegenerative diseases. During the progression of Alzheimer's disease, for example, axonal dysfunction and degeneration precedes neuronal loss. Neurodegenerative diseases often impact protein turnover and retrograde transport, suggesting that part of their etiology is the impairment of retrograde neurotrophic pathways required for neuronal maintenance. Therefore, the development of therapeutic interventions based on the use of neurotrophic factors will need to take into consideration whether the growth factor of interest only promotes local trophic effects or retrograde signaling as well.

\section{References}

Albers KM, Woodbury CJ, Ritter AM, Davis BM, Koerber HR (2006) Glial cell line-derived neurotrophic factor expression in skin alters the mechanical sensitivity of cutaneous nociceptors. J Neurosci 26:2981-2990.

Arenas E, Trupp M, Akerud P, Ibáñez CF (1995) GDNF prevents degener- 
ation and promotes the phenotype of brain noradrenergic neurons in vivo. Neuron 15:1465-1473.

Baloh RH, Tansey MG, Lampe PA, Fahrner TJ, Enomoto H, Simburger KS, Leitner ML, Araki T, Johnson EM Jr, Milbrandt J (1998) Artemin, a novel member of the GDNF ligand family, supports peripheral and central neurons and signals through the GFRalpha3-RET receptor complex. Neuron 21:1291-1302.

Buj-Bello A, Buchman VL, Horton A, Rosenthal A, Davies AM (1995) GDNF is an age-specific survival factor for sensory and autonomic neurons. Neuron 15:821-828.

Cacalano G, Fariñas I, Wang LC, Hagler K, Forgie A, Moore M, Armanini M, Phillips H, Ryan AM, Reichardt LF, Hynes M, Davies A, Rosenthal A (1998) GFRalpha1 is an essential receptor component for GDNF in the developing nervous system and kidney. Neuron 21:53-62.

Coulpier M, Ibáñez CF (2004) Retrograde propagation of GDNF-mediated signals in sympathetic neurons. Mol Cell Neurosci 27:132-139.

Deckwerth TL, Johnson EM Jr (1993) Temporal analysis of events associated with programmed cell death (apoptosis) of sympathetic neurons deprived of nerve growth factor. J Cell Biol 123:1207-1222.

Durbec P, Marcos-Gutierrez CV, Kilkenny C, Grigoriou M, Wartiowaara K, Suvanto P, Smith D, Ponder B, Costantini F, Saarma M, Sariola H, Pachnis V (1996) GDNF signalling through the Ret receptor tyrosine kinase. Nature 381:789-793.

Enomoto H, Heuckeroth RO, Golden JP, Johnson EM, Milbrandt J (2000) Development of cranial parasympathetic ganglia requires sequential actions of GDNF and neurturin. Development 127:4877-4889.

Garcès A, Haase G, Airaksinen MS, Livet J, Filippi P, deLapeyrière O (2000) GFR $\alpha 1$ is required for development of distinct subpopulations of motoneuron. J Neurosci 20:4992-5000.

Haase G, Dessaud E, Garcès A, de Bovis B, Birling M, Filippi P, Schmalbruch $\mathrm{H}$, Arber S, deLapeyrière $\mathrm{O}$ (2002) GDNF acts through PEA3 to regulate cell body positioning and muscle innervation of specific motor neuron pools. Neuron 35:893-905.

Henderson CE, Phillips HS, Pollock RA, Davies AM, Lemeulle C, Armanini M, Simmons L, Moffet B, Vandlen RA, Simpson LC (1994) GDNF: a potent survival factor for motoneurons present in peripheral nerve and muscle. Science [Erratum (1995) 267:777] 266:1062-1064.

Honma Y, Araki T, Gianino S, Bruce A, Heuckeroth R, Johnson E, Milbrandt J (2002) Artemin is a vascular-derived neurotrophic factor for developing sympathetic neurons. Neuron 35:267-282.

Jain S, Naughton CK, Yang M, Strickland A, Vij K, Encinas M, Golden J, Gupta A, Heuckeroth R, Johnson EM Jr, Milbrandt J (2004) Mice expressing a dominant-negative Ret mutation phenocopy human Hirschsprung disease and delineate a direct role of Ret in spermatogenesis. Development 131:5503-5513.

Jing S, Wen D, Yu Y, Holst PL, Luo Y, Fang M, Tamir R, Antonio L, Hu Z, Cupples R, Louis JC, Hu S, Altrock BW, Fox GM (1996) GDNF-induced activation of the ret protein tyrosine kinase is mediated by GDNFR-alpha, a novel receptor for GDNF. Cell 85:1113-1124.

Kotzbauer PT, Lampe PA, Heuckeroth RO, Golden JP, Creedon DJ, Johnson EM Jr, Milbrandt J (1996) Neurturin, a relative of glial-cell-line-derived neurotrophic factor. Nature 384:467-470.

Kramer ER, Knott L, Su F, Dessaud E, Krull CE, Helmbacher F, Klein R (2006) Cooperation between GDNF/Ret and ephrinA/EphA4 signals for motor-axon pathway selection in the limb. Neuron 50:35-47.

Kuruvilla R, Zweifel LS, Glebova NO, Lonze BE, Valdez G, Ye H, Ginty DD (2004) A neurotrophin signaling cascade coordinates sympathetic neuron development through differential control of TrkA trafficking and retrograde signaling. Cell 118:243-255.

Leitner ML, Molliver DC, Osborne PA, Vejsada R, Golden JP, Lampe PA, Kato AC, Milbrandt J, Johnson EM Jr (1999) Analysis of the retrograde transport of glial cell line-derived neurotrophic factor (GDNF), neurturin, and persephin suggests that in vivo signaling for the GDNF family is GFR $\alpha$ coreceptor specific. J Neurosci 19:9322-9331.

Levi-Montalcini R (1987) The nerve growth factor 35 years later. Science 237:1154-1162.

Li L, Wu W, Lin LF, Lei M, Oppenheim RW, Houenou LJ (1995) Rescue of adult mouse motoneurons from injury-induced cell death by glial cell line-derived neurotrophic factor. Proc Natl Acad Sci U S A 92:9771-9775.

Lin LF, Doherty DH, Lile JD, Bektesh S, Collins F (1993) GDNF: a glial cell line-derived neurotrophic factor for midbrain dopaminergic neurons. Science 260:1130-1132.
Luo W, Wickramasinghe SR, Savitt JM, Griffin JW, Dawson TM, Ginty DD (2007) A hierarchical NGF signaling cascade controls Ret-dependent and Ret-independent events during development of nonpeptidergic DRG neurons. Neuron 54:739-754.

Meng X, Lindahl M, Hyvönen ME, Parvinen M, de Rooij DG, Hess MW, Raatikainen-Ahokas A, Sainio K, Rauvala H, Lakso M, Pichel JG, Westphal H, Saarma M, Sariola H (2000) Regulation of cell fate decision of undifferentiated spermatogonia by GDNF. Science 287:1489-1493.

Milbrandt J, de Sauvage FJ, Fahrner TJ, Baloh RH, Leitner ML, Tansey MG, Lampe PA, Heuckeroth RO, Kotzbauer PT, Simburger KS, Golden JP, Davies JA, Vejsada R, Kato AC, Hynes M, Sherman D, Nishimura M, Wang LC, Vandlen R, Moffat B, Klein RD, Poulsen K, Gray C, Garces A, Johnson EM Jr (1998) Persephin, a novel neurotrophic factor related to GDNF and neurturin. Neuron 20:245-253.

Molliver DC, Wright DE, Leitner ML, Parsadanian AS, Doster K, Wen D, Yan Q, Snider WD (1997) IB4-binding DRG neurons switch from NGF to GDNF dependence in early postnatal life. Neuron 19:849-861.

Moore MW, Klein RD, Fariñas I, Sauer H, Armanini M, Phillips H, Reichardt LF, Ryan AM, Carver-Moore K, Rosenthal A (1996) Renal and neuronal abnormalities in mice lacking GDNF. Nature 382:76-79.

Mount HT, Dean DO, Alberch J, Dreyfus CF, Black IB (1995) Glial cell line-derived neurotrophic factor promotes the survival and morphologic differentiation of Purkinje cells. Proc Natl Acad Sci U S A 92:9092-9096.

Oppenheim RW, Houenou LJ, Johnson JE, Lin LF, Li L, Lo AC, Newsome AL, Prevette DM, Wang S (1995) Developing motor neurons rescued from programmed and axotomy-induced cell death by GDNF. Nature 373:344-346.

Oppenheim RW, Houenou LJ, Parsadanian AS, Prevette D, Snider WD, Shen L (2000) Glial cell line-derived neurotrophic factor and developing mammalian motoneurons: regulation of programmed cell death among motoneuron subtypes. J Neurosci 20:5001-5011.

Paratcha G, Ledda F, Ibáñez CF (2003) The neural cell adhesion molecule NCAM is an alternative signaling receptor for GDNF family ligands. Cell 113:867-879.

Pichel JG, Shen L, Sheng HZ, Granholm AC, Drago J, Grinberg A, Lee EJ, Huang SP, Saarma M, Hoffer BJ, Sariola H, Westphal H (1996) Defects in enteric innervation and kidney development in mice lacking GDNF. Nature 382:73-76.

Pierchala BA, Milbrandt J, Johnson EM Jr (2006) Glial cell line-derived neurotrophic factor-dependent recruitment of Ret into lipid rafts enhances signaling by partitioning Ret from proteasome-dependent degradation. J Neurosci 26:2777-2787.

Poteryaev D, Titievsky A, Sun YF, Thomas-Crusells J, Lindahl M, Billaud M, Arumäe U, Saarma M (1999) GDNF triggers a novel ret-independent Src kinase family-coupled signaling via a GPI-linked GDNF receptor alphal. FEBS Lett 463:63-66.

Pozas E, Ibáñez CF (2005) GDNF and GFRalphal promote differentiation and tangential migration of cortical GABAergic neurons. Neuron 45:701-713.

Rosenblad C, Grønborg M, Hansen C, Blom N, Meyer M, Johansen J, Dagø L, Kirik D, Patel UA, Lundberg C, Trono D, Björklund A, Johansen TE (2000) In vivo protection of nigral dopamine neurons by lentiviral gene transfer of the novel GDNF-family member neublastin/artemin. Mol Cell Neurosci 15:199-214.

Sánchez MP, Silos-Santiago I, Frisén J, He B, Lira SA, Barbacid M (1996) Renal agenesis and the absence of enteric neurons in mice lacking GDNF. Nature 382:70-73.

Sanicola M, Hession C, Worley D, Carmillo P, Ehrenfels C, Walus L, Robinson S, Jaworski G, Wei H, Tizard R, Whitty A, Pepinsky RB, Cate RL (1997) Glial cell line-derived neurotrophic factor-dependent RET activation can be mediated by two different cell-surface accessory proteins. Proc Natl Acad Sci U S A 94:6238-6243.

Scott RP, Eketjäll S, Aineskog H, Ibáñez CF (2005) Distinct turnover of alternatively spliced isoforms of the RET kinase receptor mediated by differential recruitment of the $\mathrm{Cbl}$ ubiquitin ligase. J Biol Chem 280:13442-13449.

Treanor JJ, Goodman L, de Sauvage F, Stone DM, Poulsen KT, Beck CD, Gray C, Armanini MP, Pollock RA, Hefti F, Phillips HS, Goddard A, Moore MW, Buj-Bello A, Davies AM, Asai N, Takahashi M, Vandlen R, Henderson CE, Rosenthal A (1996) Characterization of a multicomponent receptor for GDNF. Nature 382:80-83. 
Trupp M, Rydén M, Jörnvall H, Funakoshi H, Timmusk T, Arenas E, Ibáñez CF (1995) Peripheral expression and biological activities of GDNF, a new neurotrophic factor for avian and mammalian peripheral neurons. J Cell Biol 130:137-148.

Trupp M, Scott R, Whittemore SR, Ibáñez CF (1999) Ret-dependent and -independent mechanisms of glial cell line-derived neurotrophic factor signaling in neuronal cells. J Biol Chem 274:20885-20894.

Tsui-Pierchala BA, Ginty DD (1999) Characterization of an NGF-P-TrkA retrograde-signaling complex and age-dependent regulation of TrkA phosphorylation in sympathetic neurons. J Neurosci 19:8207-8218.

Tsui-Pierchala BA, Milbrandt J, Johnson EM Jr (2002a) NGF utilizes c-Ret via a novel GFL-independent, inter-RTK signaling mechanism to maintain the trophic status of mature sympathetic neurons. Neuron 33:261273 .
Tsui-Pierchala BA, Ahrens RC, Crowder RJ, Milbrandt J, Johnson EM Jr (2002b) The long and short isoforms of Ret function as independent signaling complexes. J Biol Chem 277:34618-34625.

Vega QC, Worby CA, Lechner MS, Dixon JE, Dressler GR (1996) Glial derived neurotrophic factor is a ligand for RET and promotes kidney morphogenesis. Proc Natl Acad Sci U S A 93:10657-10661.

Whitehead J, Keller-Peck C, Kucera J, Tourtellotte WG (2005) Glial cell-line derived neurotrophic factor-dependent fusimotor neuron survival during development. Mech Dev 122:27-41.

Wright DE, Snider WD (1996) Focal expression of glial cell line-derived neurotrophic factor in developing mouse limb bud. Cell Tissue Res 286:209-217.

Yan Q, Matheson C, Lopez OT (1995) In vivo neurotrophic effects of GDNF on neonatal and adult facial motor neurons. Nature 373:341-344. 